\title{
A KOHÉZIÓS POLITIKA \\ VÁLTOZÁSAINAK \\ ÉS EREDMÉNYESSÉGÉNEK HATÁSAI A VÁLLALATI DÖNTÉSHOZATALRA
}

A vállalati szféra döntéshozói szempontjából fontos mérlegelési aspektust képez az európai uniós forrásokból megvalósuló fejlesztéspolitika alakulása, eredményessége. Ezek a tényezók beépülnek a döntési modellekbe is. A vállalatvezetốk számára a költség- és idôigényesség a legfontosabb mérlegelési szempont. Ezek alapján átlátható döntési mechanizmusokra, egységes eljárási rendekre, gyors és egyszerú adminisztrációra, ügyfélközpontú, hatékony intézményrendszerre van szükség. Az ötödik kohéziós jelentés megjelenése ismét az érdeklódés középpontjába helyezte az Európai Unióban a kohéziós politikát. A továbbra is jelen lévő gazdasági, szociális és területi egyenlôtlenségek oldása érdekében szükség van olyan fejlesztéspolitikai eszközrendszerre, amely egyszerre szolgálhatja a versenyképesség erôsítését és a konvergenciát.

Kulcsszavak: döntési modellek, fejlesztéspolitika, kohéziós politika, értékelés

Komoly egyenlőtlenségek indokolták az Európai Unióban a kohéziós politika létrehozását. Elemzésemben feltárom azt, hogyan alakult ez a terület az elmúlt időszakban, különösen a legutóbbi években megjelent új irányzatok tükrében. Ezek után empirikus vizsgálatban elemzem a politika hatásait a jövedelmek alakulásának területén.

Mindezek előtt bemutatom azokat a szempontokat, amelyek a vállalatok, vállalkozások számára a fejlesztéspolitika kapcsán fontosak lehetnek. A fejlesztéspolitikai források allokációja, hatásossága, eredményessége több okból is érdekes lehet a gazdálkodó szervezetek, és ezen belül a vállalatok, vállalatvezetók számára:

- egyrészt a fejlesztési támogatások (vissza nem térítendő támogatások, kamatkedvezményes hitelek) hasznosak lehetnek a források bóvitése kapcsán, vagyis számos olyan gazdasági szereplő létezik, amely korábban már igénybe vett támogatást, vagy esetleg a szabályok egyszerúsödése esetén szívesen igénybe venne pályázati forrást,

- másrészt a támogatások akár közvetetten is szolgálhatják egy adott szervezet érdekeit, még ha az a gazdálkodó nem is vesz igénybe pályázati for- rást, de beszállítói, partnerei, versenytársai igen, ezáltal a versenyhelyzetre, az alkuerókre befolyást gyakorol a fejlesztéspolitika,

- harmadrészt fontos befolyásoló szereppel rendelkeznek a források, mivel képesek módosítani, alakítani a gazdasági aktivitás térbeli koncentrációjának elhelyezkedését, ezáltal érdemes figyelembe venni a vállalati döntéshozóknak is, hogy milyen támogatási források milyen vállalati kör fejlesztését szolgálják. (Ugyanakkor fontos kiemelni, hogy a közvetlen múködőtókeberuházások általában jóval nagyobb nagyságrendet érnek el a fejlesztéspolitikai forrásoknál, így ezek dominánsabb szereppel rendelkeznek a térstruktúra alakításában.)

A fenti szempontok együttes érvényesítése azonban nem segíti elố az állami beavatkozások egy adott prioritás mentén történő szerveződését, mivel ez esetben adott ágazatokat szükséges preferálni. Ilyen szempontból is hasznos, ha a támogatások a gazdasági szférában nem közvetlenül az adott vállalkozásokat célozzák meg, hanem a gazdasági környezetet, a tágan értelmezett inf- 
rastruktúrát (fizikai elemek, modern kommunikációs rendszerek), az állami intézményrendszer modernizációját, hiszen ez által a gazdálkodó szervezetek múködési költségei csökkenhetnek, és ez az általános versenyképességük javulásához vezet.

A konkrét vállalati (vagy mikro) szinten érdemes a döntési modellek segítségével vizsgálni a szituációkat. Döntések esetén egy tipikus folyamat során a menedzserek elôször a probléma felismerésével és meghatározásával foglalkoznak, majd kidolgozzák és elemzik a lehetséges megoldásokat. $\mathrm{Az}$ egyik megoldási alternatíva kiválasztása és etikai ellenőrzése után következik a megoldás végrehajtása és az eredmények értékelése. A téma kapcsán a második szakasz, vagyis a lehetséges megoldások kidolgozása és elemzése az igazán releváns, mivel itt kell figyelembe venniük a vállalati döntéshozóknak a fejlesztéspolitika által kínált lehetőségeket, opciókat, hatásokat (1. ábra). A megfeleló megoldás megtalálása érdekében szükséges az információgyuújtés és az adatelemzés (2. ábra). A lehetôségek közötti döntés során a következó szempontokat szükséges figyelembe venni: előnyök, költségek, idôtényezô, elfogadhatóság, etikai korrektség. Az értékelés során szükséges költség-haszon elemzést is végezni (Farkas et al., 2007).

Ezek után érdemes megvizsgálni, hogy a gazdasági szféra szereplói számára milyen forrásallokációs rendszer lenne igazán megfeleló, azaz milyen elvárásokkal rendelkeznek a konkrét fejlesztéspolitikai eszközrendszerrel szemben. A leginkább releváns szempontok a A kohéziós politika kapcsolódása a döntési folyamatokhoz

A fejlesztéspolitikai eszközrendszer kínálta lehetôségek illeszkedése a vezetôi döntési modellekhez

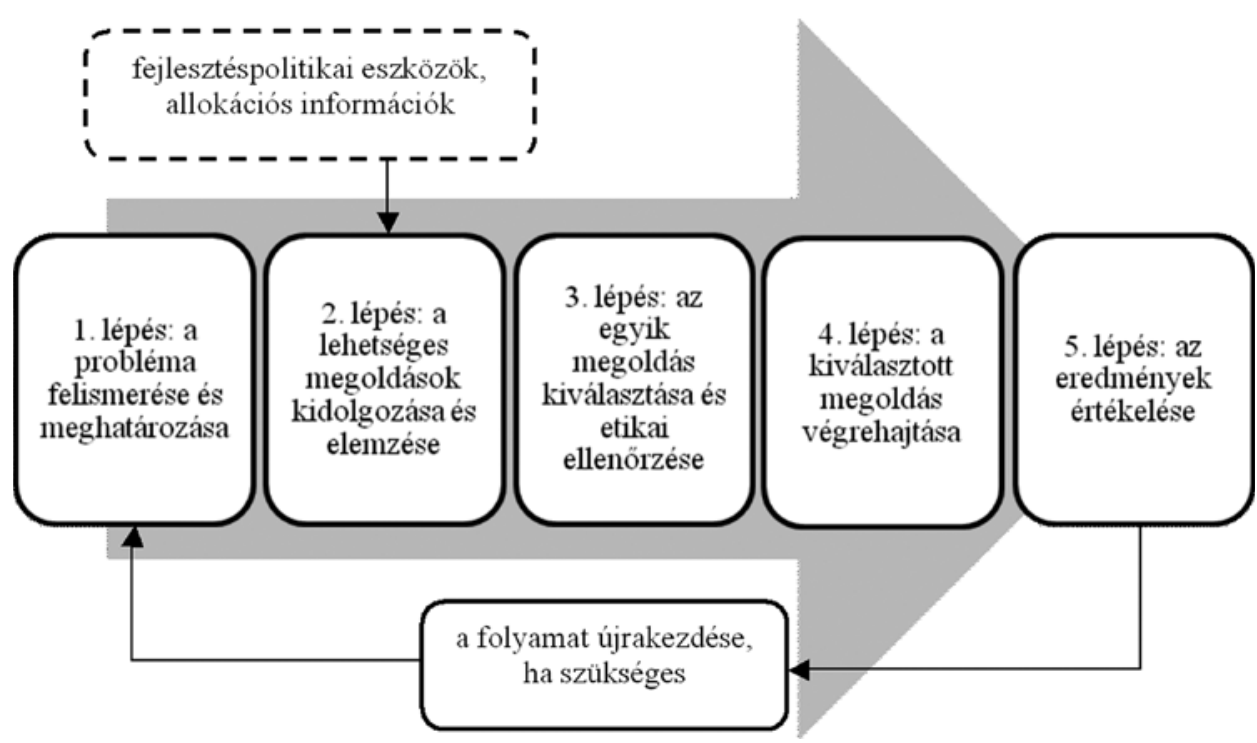

Forrás: Farkas F. - Hadinger B. - Szúcs P. (2007): A menedzsment alapjai. Pécs: PTE KTK, 201. o. alapján saját szerkesztés

- gyors forráshoz jutás, egyszerú adminisztráció (alacsony adminisztrációs költségek),

- egyszerú pályázati rendszer, automatikus elbírálás kisebb összegú pályázatoknál,

- követhető forrásallokáció, nyílt információk, elérhetô adatok,

- verseny és ágazatsemlegesség fenntartása,

- versenyképesség erősítése, eredményesség, hatékonyság figyelembevétele,

- olcsón fenntartható, hatékony, ügyfélközpontú intézményrendszer.

Az európai uniós források felhasználását befolyásoló kohéziós politika alakulásának bemutatása során a fenti szempontok érvényesülését érdemes megvizsgálni, áttekinteni.

2. ábra következók:

- átlátható döntési mechanizmusok, egyértelmú szabályozás,

- egységes eljárási rendek, függetlenül az adott pályázat irányultságától,

Döntési folyamatokhoz szükséges információk

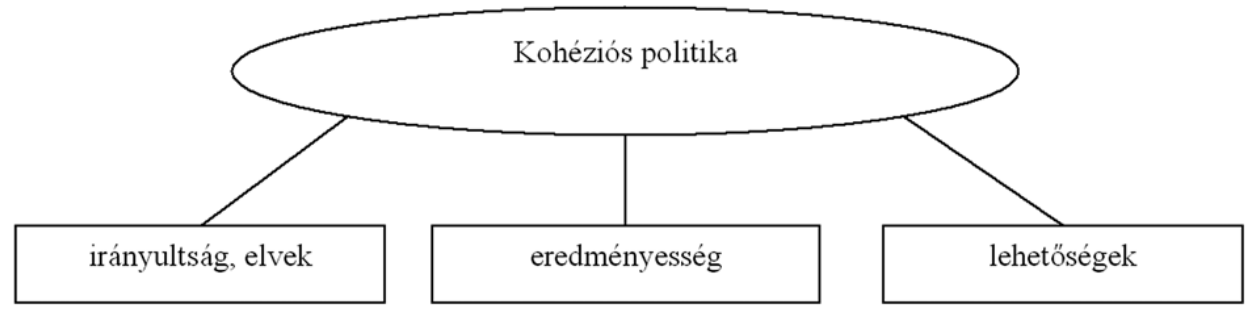

Forrás: saját szerkesztés 


\section{Egyenlốtlenségek dimenziói - a fejlesztés- politikai beavatkozások indokoltsága}

„A gazdaság és társadalom fejlődése természetszerúleg és minden esetben térben egyenlótlen" (Enyedi, 2010: p. 398.). Az Európai Unióban igen komoly mértékú egyenlőtlenségek jellemzőek a tagállamok között és a tagállamokon belül. Az európai gazdasági tér több szempontból tagolt (Horváth, 2004). Az egyenlőtlenségek fennállása mellett fontos tényezố, hogy Európában a területi differenciáltság mértékének folyamatos növekedése figyelhetô meg. A 2004-es bővítés eredményeképpen a területi egyenlótlenségek további fokozódása valósult meg (Kengyel, 2008), az elmaradott térségek száma, lakossága nagymértékben nőtt (Horváth, 2006). Magyarországon erőteljes térbeli koncentráció jellemzô (Lukovics, 2006), a gazdasági, szociális, területi egyenlótlenségek folyamatosan fokozódnak, a fejlett és kevésbé fejlett térségek közötti különbség folyamatosan nő (Horváth, 1996; Horváth, 2010).

Az egyes térségeket eltérô mértékben érintô gazdasági növekedés még a legkevésbé fejlett országokban is területi egyenlótlenségeket okozott. Mindezek alapján szükség van olyan eszközökre, amelyek képesek az egyenlőtlenségeket csökkenteni. Az EU egyik legfontosabb prioritása, hogy minél nagyobb mértékú gazdasági és szociális kohéziót tudjon megvalósítani. A kohéziós politika nagyságrendje az integráció fejlődésével párhuzamosan alakult, a kohézió erôsítése és a fejlettségbeli különbségek felszámolása érdekében elköltött összegek több, mint megduplázódtak az 1980as évek vége óta, ezáltal a fejlesztéspolitika az ezredfordulóra a második legjelentősebb politikává vált az EU-n belül (Rodriguez - Fratesi, 2002). Mostanra az Európai Unió egyik legnagyobb kiadási tétele a közös költségvetésen belül a kohéziós politika.

Legfontosabb üzenetek, célok megjelenése a kohéziós politika fejlődése során

\begin{tabular}{|l|l|}
\hline Dokumentum címe, megjelenés évsz. & \multicolumn{1}{c|}{ Üzenet } \\
\hline Zöld Könyv, 2008 & területi kohézió \\
\hline Barca jelentés, 2009 & $\begin{array}{l}\text { helybázisú fejlesztések, hatékonyság és } \\
\text { kiegyenlítés elkülönítése, reform szükségessége }\end{array}$ \\
\hline Európa 2020 stratégia, 2010 & intelligens, fenntartható és inkluzív növekedés \\
\hline Ötödik kohéziós jelentés, 2010 & $\begin{array}{l}\text { koordináló szerepkör, források koncentrációja, } \\
\text { területi kohézió, földrajzi sajátosságok, partnerség }\end{array}$ \\
\hline
\end{tabular}

A vállalati szféra szempontjából az elmúlt időszakban a kohéziós politika alakulása kapcsán körvonalazódó fejlesztési irányok (1. táblázat) komoly előrelépést, megfelelő megoldásokat jelentenek, illeszkednek az elôzőekben bemutatott szempontrendszerhez. Ugyanterületén hazánkban.

akkor fontos kiemelni, hogy a korábbiak során is számos esetben jelent meg olyan nyilatkozat, dokumentum, amely az egyszerúsítést túzte ki célul, míg végül ezek nem okoztak jelentôs csökkenést az adminisztrációs feladatokban, nem eredményezték a forrásokhoz való hozzájutás egyszerúsödését.

Összességében ezen irányok alapján a kohéziós politika valószínúleg választ tud adni azokra a kihívásokra, amelyek az elmúlt évtizedben felmerültek. Ugyanakkor továbbra is kérdéses, hogy a meglévố centrum-periféria viszonyrendszerben mekkora hatásfoka lehet ennek a típusú redisztribúciónak a fejlesztések területén a piaci erókhöz képest (Lóránd, 2010). Ennek felmérése, megítélése érdekében a következókben elemezni fogom a kohéziós politika felzárkóztató hatását a jövedelmek

\section{Fejlesztéspolitika európai uniós forrásokból Magyarországon}

A hazai gazdaság rendkívül nagymértékben függ a külföldi forrásoktól (Bélyácz - Kuti, 2009). Emellett az ország egyes térségei eltéró mértékú külföldi tốkebefektetést tudnak felmutatni (Benedek, 2001). A globális gazdasági és pénzügyi válság felhívta a figyelmet arra is, hogy a közép- és kelet-európai tagországok nem építhetik felzárkózásukat kizárólag a külföldi múködő tőkén alapuló növekedésre (Nagy, 2010; Szerb, 1994). Ez a fajta túlzott függés nem szerencsés a gazdaság számára, ezért Magyarországon is fontos a $k k v-k$ megerốsödése. A kkv-k támogatásánál figyelembe kell venni, hogy az eddigi ilyen irányú vizsgálatok alapján a nem normatív jellegú támogatások nem igazán segítik a vállalkozókat, akik támogatásban részesültek, azok is többnyire nem a növekedés érdekében használták

1. táblázat azt fel (Dezsériné Major, 2008). A kkv-k jelentős szerepet töltenek be a hazai gazdaságban: a foglalkoztatottak kétharmadát kötik le, a GDP felét, az export hozzávetóleges egyharmadát állították eló az ezredfordulón. Emellett az újonnan létrejövố cégeknek nagy szerepe van a munkahelyteremtésben, a gazdasági növekedés erôsítésében és az innovációk létrehozásában (Szerb et al., 2004). A vállalkozások támogatása kapcsán fontos a hálózatos összefogás erósítés, a képzési tevékenységek kialakítása, valamint a hitel- és támogatási programok létrehozása (Hrubi, 2001). Emellett szükséges lenne a szabályozási környezet, a pályázati rendszer egyszerúsítése, a kifizetések felgyorsítása, az 
automatikus pályázás elősegítése. Ezek jelentik azokat a fejlesztési irányokat, amelyeket az Európai Uniós források fejlesztésre vonatkozó felhasználása esetén követni érdemes. A kohéziós politika megvalósulásának hazai vizsgálatánál tehát elsőrendú kérdés megnézni azt, hogy mennyiben követi a felsorolt irányokat, pályákat.

Az I. Nemzeti Fejlesztési Terv fő célja az EU átlagához viszonyított jövedelemkülönbségek csökkentése (NFH, 2006), és így az életminőség javítása. A dokumentum stratégiája tartalmazza a regionálisan kiegyenlítettebb fejlódés megvalósításának szükségességét Magyarországon (NFH, 2004). A kérdés így az, hogy az országon belüli területi egyenlőtlenségek mérsékléséhez várhatóan hogyan járult hozzá az I. NFT.

A támogatási rendszer hazai kiépülése, amelyen belül a Strukturális Alapok és a Kohéziós Alap csak két forrásként jelenik meg, 2004-re a GDP 1,3\%-át eredményezô újraelosztáshoz vezetett Magyarországon, mindebból a Strukturális Alapok keretében érkezett közösségi támogatás 0,58\%-ot tett ki (Voszka, 2006). Ez egy igen alacsony arányt jelent, még akkor is, ha 2006-ra már elérte az 1\%-ot. Dilemmát okozhat annak megítélése, hogy vajon ezek a források mennyire jelentenek elegendô fejlesztési pénzt az országnak, vagyis a nemzeti jövedelemhez viszonyított arányuk alapján mennyire képesek tényleges fejlesztési, felzárkóztatási hatást gyakorolni a hazai gazdaságra, társadalomra. Ennek vizsgálatára kerül sor az empirikus részben.

Összességében kijelenthetô, hogy az Európai Unióval kapcsolatban komoly (irreális) várakozások jelentek meg Magyarországon, amelyek a nagy összegú támogatások miatt konvergencia bekövetkezését valószínúsítették (Kornai, 2007). Az ország felzárkózása mellett fontos törekvés a különböző térségek közötti területi különbségek mérséklése is (Adler, 1999). Ugyanakkor modellszámításokkal kutatók igazolták, hogy a lehetô legnagyobb országos GDP-növekedés érdekében a forrásokat a központi régióra szükséges koncentrálni (Járosi et al., 2009; Varga, 2007). Az I. NFT alatt jóval kevesebb támogatás érkezett hazánkba, a II. NFT már jelentősebb forrásokat mozgat meg, kérdéses, hogy mindez mekkora hatással bír a jövedelmek, az életszínvonal alakulása kapcsán.

\section{A fejlesztéspolitika értékelése}

Alapvető feladat a kohéziós politika értékelésének területén annak számszerúsítése, hogy a fejlesztésekre elköltött összegek milyen hatásfokkal hasznosulnak, és mi okozza az adott beavatkozások sikerét vagy kudarcát (Lóránd, 2009). Az európai uniós tagság következtében egyre jobban elótérbe került az értékelés fontossága Magyarországon is.

A hazánkban elkészült értékelő jelentések program és politika szinten leginkább az I. Nemzeti Fejlesztési Terv területi allokációs mechanizmusainak feltárásával foglalkoztak. Komoly kritikaként fogalmazható meg az értékelő tanulmányok kapcsán a hazai értékelést végzókkel (illetve az értékelések megrendelőivel) szemben, hogy számos vizsgálat, közpénzból finanszírozott (általában több száz oldalas) tanulmány készült el úgy, hogy a területi szempontok szerinti komplex elemzés hiányzik az anyagból. Kivételnek számítanak azok az anyagok, amelyek a regionális, megyei, illetve kistérségi szinteken vizsgálódtak (lásd Csengódi et al., 2006; Csite - Németh, 2006, 2008; DDRFÜ, 2007; Ecostat, 2008; HBF, 2006; Lehmann, 2008; MEH, 2006; NFH 2006; NFÜ 2007, 2008; Toroczkai - Hahn, 2006).

Jelen értékelés során az eredményeket fogom összehasonlítani az inputokkal, vagyis a fejlesztési források nagyságrendjével. Az értékelés során a cél a hatékonyság felmérése (Rechnitzer - Lados, 2004), amelynek lényege az elért eredmények, hatások és a hozzájuk szükséges költségek (inputok) viszonyának számszerúsítése (3. ábra). Mivel a 2004-2006-os időszak elemzése a cél, ezért ez egy utólagos (ex-post) értékelésnek minősíthető.

3. ábra

Folyamatok és értékelési fogalmak viszonyrendszere

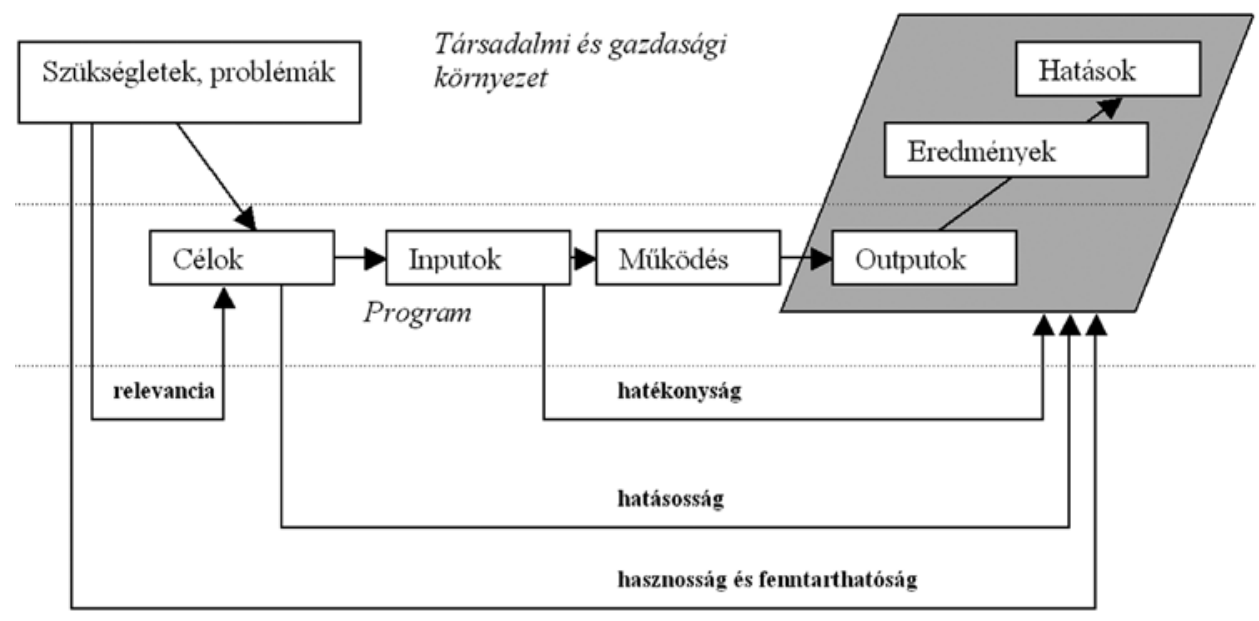

Forrás: Molle, W. (2007): European Cohesion Policy. London-New York, Routledge, 227. o. és Rechnitzer J. - Lados M. (2004): A területi stratégiáktól a monitoringig. Módszertan, gyakorlati praktikumok. Budapest-Pécs, Dialóg Campus Kiadó, 260. o. 


\section{A jövedelmek változása és}

\section{a támogatások nagyságrendje az I. NFT alapján - empirikus vizsgálat}

Az empirikus elemzés célja feltárni, hogy a kistérségekben kimutatható jövedelmek változása mennyiben függ össze az adott kistérség támogatottságának nagyságával. Mindezek alapján következtetni lehet arra, hogy az I. NFT keretei között hazánkba érkező EU-támogatások pályázati forrásai képesek-e olyan mértékú szignifikáns hatást gyakorolni a jövedelmekre, amely kimutatható és pozitív. Kérdéses, hogy egyáltalán ezek a források összefüggésben állnak-e az adott térség jövedelmének alakulásával.

A kiinduló hipotézis szerint az I. NFT támogatásai a 2004-2006 közötti idôszakban képesek voltak hatást gyakorolni az egyes kistérségek jövedelmi szintjére, mivel az abszolút és relatív (tehát fajlagos) mértékben nagyobb támogatásokat felszívó kistérségek esetében bizonyítottan nagyobb adóalapot képező jövedelem jött létre, mint azokban a kistérségekben, amelyek kevesebb támogatásban részesültek.

A kutatás során azokat a támogatásokat vizsgáltam meg, amelyekról a 2004, 2005 és 2006 években döntöttek, mivel ezek jelentik az I. NFT kapcsán kifizetett bejelentett álláshelyeket, jövedelmeket generáltak, viszont előfordulhat, hogy egy korábban nem hivatalosan létezố munkahelyet váltottak ki, amely így nem tekinthetố valós előrelépésnek, növekedésnek, viszont a statisztikák alapján annak túnik.

A kistérségek száma a vizsgált idôszakban megváltozott, létrejött hat új kistérség, illetve 28 kistérség településeinek köre szúkuült, míg 22 kistérségé bôvült. Ezeket a konzekvens összehasonlítás érdekében kivettem a vizsgálatból. Ez összesen (az átfedések miatt) 49 kistérséget jelent, vagyis összesen 125 kistérséget tudtam megvizsgálni. A vizsgált elemek a teljes sokaság 74,4\%-át jelentik népességarányosan, tehát a kizárások után is a sokaság kb. háromnegyede benne maradt az elemzésben.

A vizsgálat céljának és hipotézisének megfelelően olyan változókat (2. táblázat) választottam ki az elemzés érdekében, amelyek a jövedelmi szintek alakulását képesek megragadni. Továbbá fontos szempont volt az is, hogy a KSH $(2005$; 2009) területi adatai között megtalálhatóak legyenek, és konzekvensen megjelenjenek a 2004 és a 2008-as évben is, mivel ebben a periódusban vizsgáltam a jövedelmek alakulását. A támogatási adatok az Egységes Monitoring és Információs Rendszerból származnak. ${ }^{1}$

2. táblázat

\section{Vizsgált változók az elemzés során}

\begin{tabular}{|l|l|}
\hline adóalap változása 2004 és 2008 között a kistérségben & $\begin{array}{l}\text { 2004-2006 között megítélt I. NFT támogatási összeg a kistérség } \\
\text { számára }\end{array}$ \\
\hline $\begin{array}{l}\text { adózók számának változása } 2004 \text { és } 2008 \text { között } \\
\text { a kistérségben }\end{array}$ & 2004-2006 között megítélt egy lakosra jutó I. NFT támogatási összeg \\
\hline $\begin{array}{l}\text { egy adózóra jutó jövedelem nagysága } 2004 \text { és } 2008 \text { között } \\
\text { a kistérségben }\end{array}$ & \\
\hline
\end{tabular}

Forrás: saját szerkesztés

támogatási összegek legnagyobb hányadát, ezek kifizetése is (az N+2 szabály miatt) sok esetben elhúzódott a következô évekre, valós, kimutatható hatást ezért inkább középtávon érdemes várni esetükben. Ezért a vizsgált időszak a jövedelmek alakulása kapcsán a 2004 és a 2008 közötti periódus, amely már alapot teremt arra, hogy a hatások (középtávú) felmérését is megkíséreljük. (Ugyanakkor érdemes megjegyezni, hogy a hosszú távú hatások felmérése érdekében jobb megoldást jelentene egy még hosszabb időperiódus, ebben az esetben viszont már problémát okozna, hogyan lehetne elkülöníteni egymástól az I. NFT és a II. NFT hatásait.)

A vizsgálat kapcsán meg kell említeni, hogy a fekete-és szürkegazdaság jelensége természetesen torzítja az adatokat és a számítások minôségét, ugyanakkor az uniós támogatásokkal létrejött fejlesztések hivatalosan
A korrelációelemzés eredményei alapján megállapítható, hogy a vizsgált változók közül az adott kistérségbe jutó teljes NFT-támogatás és a jövedelmek változásai ténylegesen együtt mozognak, amit a magas korrelációs érték mutat (0,984; legalább 1\%-os szignifikancia szintnél elfogadható). Mindez azt jelenti, hogy azon kistérségekben, ahol jelentôsen nôtt az SZJA-alapot képezó jövedelem, igen komoly abszolút értékú támogatás érkezett az I. NFT keretei között 2004 és 2006 közötti időszakban. Továbbá azon kistérségekben, ahol az összjövedelem nem nótt jelentősen abszolút értékben (vagy akár stagnált vagy csökkent) jellemzően kevés támogatás érkezett az I. Nemzeti Fejlesztési Tervból a vizsgált időszakban. Az adófizetôk számának változását felhasználva a parciális korrelációs számításban kontrollváltozóként kiderült, hogy a korreláció 
így is hasonló mértékú $(0,987)$, vagyis önmagában az adózók számának változása nem hat a két változó alakulására. (A többi, vizsgálatba bevont változó között csak gyenge szignifikáns kapcsolat mutatható ki.)

Ez nem bizonyítja még egyértelmúen, hogy az EU-s támogatásoknak közvetlenül jelentős jövedelemnövelő hatásuk lenne, ugyanakkor felhívja a figyelmet arra, hogy a komoly mértékú támogatást sikeresen elnyerô (és felhasználó) térségekben a hivatalos összjövedelem jelentôs mértékben emelkedett - ezek tekinthetőek növekedési és felzárkózási szempontból is a leginkább sikeres térségeknek. Míg azon területek, ahol alacsony jövedelemváltozás figyelhetô meg, oda az EU-s támogatásokból is jóval kevesebb jutott. Budapest (eltérő nagyságrendje miatti) kizárása után az összefüggés a két vizsgált változó között vizuálisan is bemutatható, ez alapján megállapítható, hogy a kistérségek egy pozitív meredekségú egyenes mentén helyezkednek el (4. ábra).

Kistérségek ábrázolása a támogatások és a jövedelmek változásának függvényében

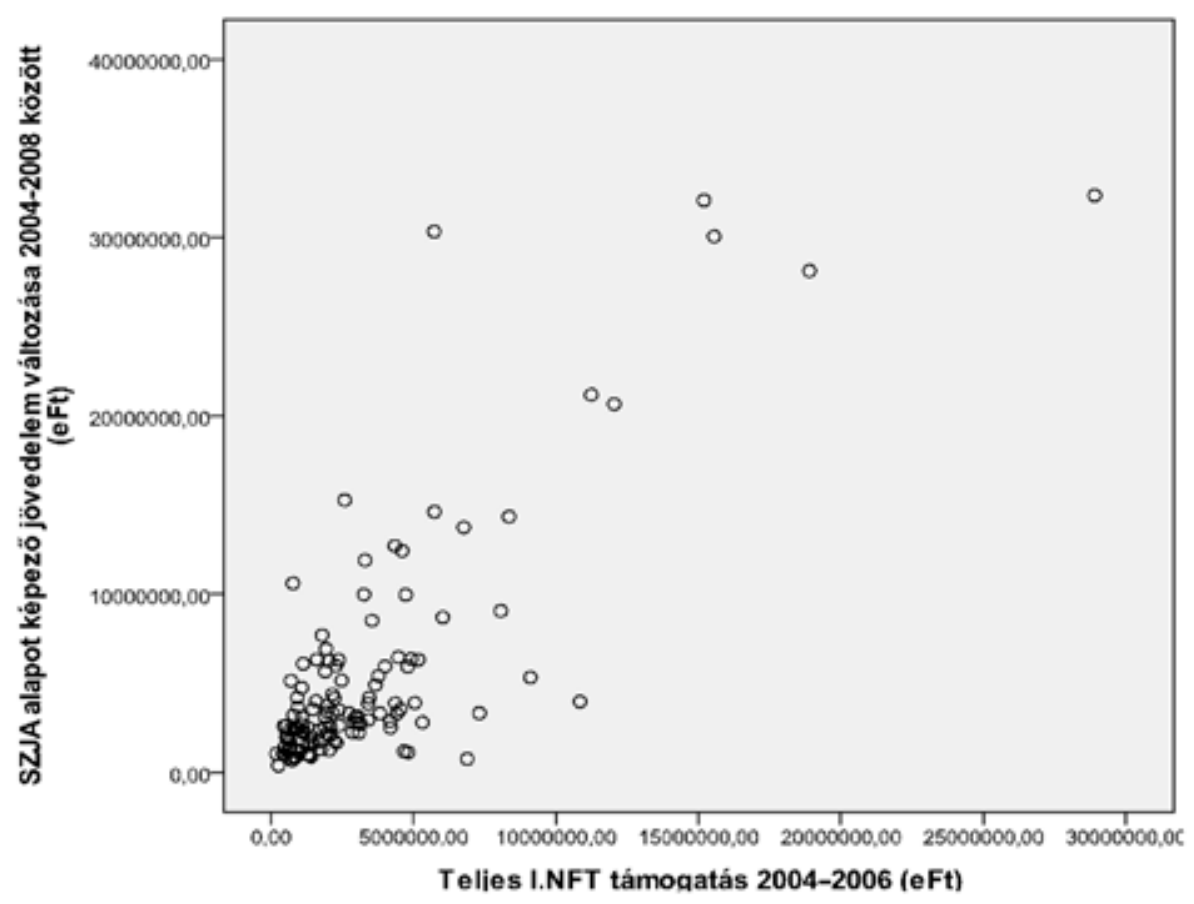

Forrás: saját szerkesztés

A vizsgálat következő fázisában a fajlagos értékek közötti összefüggést próbáltam bebizonyítani, hiszen hasonló eredmények esetén egyértelmú lenne a két változó együttmozgása. Az elemzéshez a klaszteranalízis módszertanát használtam fel, mivel ez robosztus eszköznek minősíthetô, vagyis kevésbé érzékeny a vizsgált sokaság normalitástól eltéró jellegzetességeire. Ugyanakkor ennél a módszernél is érdemes kizárni azokat a kistérségeket, amelyek kiugró adatokkal, jellemzókkel rendelkeznek. Az egy adózóra jutó jövedelemváltozás (2004-ról 2008-ra 2008-as árakon kalkulálva) és az egy lakosra jutó teljes I. NFT támogatás alapján hierarchikus Ward-módszerrel (négyzetes euklideszi távolság felhasználásával) három homogén klasztert hoztam létre (3. táblázat és 5. ábra).

3. táblázat

A létrejött klaszterek jellemzói

\begin{tabular}{|l|c|c|c|c|}
\hline & 1. klaszter & 2. klaszter & 3. klaszter & fóátlag \\
\hline $\begin{array}{l}\text { Egy lakosra jutó NFT } \\
\text { elnyert támogatás (eFt) } \\
\text { 2004-2006 }\end{array}$ & 52,2 & 129,1 & 62,6 & 66,2 \\
\hline $\begin{array}{l}\text { Egy adófizetóre jutó } \\
\text { SZJA alapot képezó } \\
\text { jövedelem változása } \\
\text { (eFt) 2004-2008 között }\end{array}$ & 189,7 & 183,3 & 253,2 & 215 \\
\hline
\end{tabular}

4. ábra

Forrás: saját szerkesztés

Ezen klaszterek közül az elsố tagjai átlag alatti támogatásban részesültek, illetve a megfigyelhetô jövedelemnövekedés is átlag alatti volt. A második klaszter tagjai közel az átlagosnak a kétszeresét kapták támogatásként, míg a jövedelemnövekedés nagysága itt is az átlagos alatt volt. A harmadik klaszter tagjai átlagos nagyságú EU-s támogatásokban részesültek, míg a jövedelmek növekedése átlag feletti volt. Mindez jelentősen árnyalja a korábbi eredményeket. Tehát különböző módszertanok segítségével nem sikerült egyértelmúen bizonyítani, hogy a támogatások növelték a jövedelmeket: az abszolút és a fajlagos értékekkel végzett számítások eltérő eredményre vezettek, így nem bizonyítható egyértelmúen az I. NFT jövedelemnövelő hatása kistérségi szinten (5. ábra).

Az elemzés eredményei kapcsán fontos arra is felhívni a figyelmet, hogy a vizsgált jelenségek mögött természetesen állhat másik változó is, amely akár hatást gyakorolhat mindkét vizsgált változó alakulására is. Az alkalmazott vizsgálatnál ez a változó lehetne például a külföldi befektetett tóke nagysága, amelynek értéke viszont kistérségi szinten nem elérhetô a statisztikai adatbázisokból. 
Kistérségek ábrázolása a támogatások és a jövedelmek változásának fajlagos értékeinek függvényében

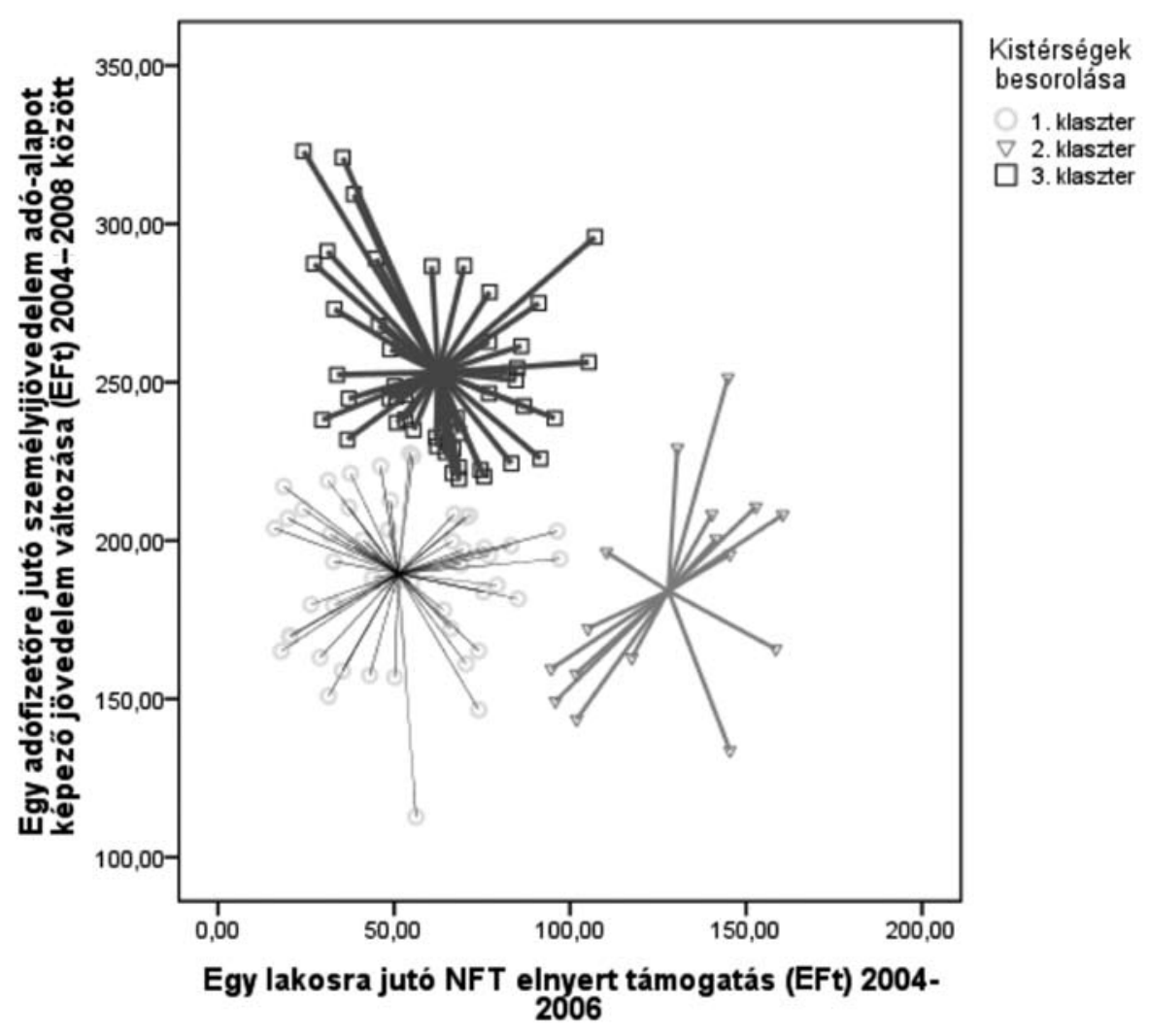

Forrás: saját szerkesztés

\section{Összegzés}

A vállalati szféra döntéshozói számára is fontos mérlegelési szempontot, döntést befolyásoló információt jelent a megvalósuló fejlesztéspolitika eszközrendszere, allokációja. Mindezek beépülnek a döntési modellekbe. A vállalatvezető́k szempontjából a költség- és időigényesség jelenti a legfontosabb mérlegelési szempontot. Ezek alapján átlátható döntési mechanizmusokra, egységes eljárási rendekre, gyors és egyszerú adminisztrációra, ügyfélközpontú, hatékony intézményrendszerre van szükség a pályázatok világában. A kohéziós politika reformjával kapcsolatban megjelent dokumentumok az elmúlt időszakban kifejezetten hangsúlyozzák az említett szempontok fontosságát is, ezért várható, hogy a 2014-2020 közötti időszakban előrelépés történik ezen a területen is.

A hazánkba érkezett és érkezô fejlesztési források az elmúlt években már jelentôs nagyságrendet értek el, ugyanakkor a gyors konvergencia megvalósítására nem képesek. A tanulmányban bizonyítottam, hogy bár az abszolút értéken vett I. NFT támogatások és az SZJA-alapot képezó jövedelmek együttmozogtak a
4. ábra vizsgált kistérségekben, ugyanakkor a fajlagos adatoknál (vagyis az egy adózóra vagy egy lakosra jutó értékeknél) ugyanez a tendencia már nem mutatható ki, tehát nem egyértelmúen bizonyítható a fejlesztési források felzárkóztató hatása. A legújabb támogatási tervek (Új Magyarország Fejlesztési Terv, Új Széchenyi Terv) ugyanakkor jóval nagyobb forrásallokációt valósítanak meg hazánkban, ezért ezek kapcsán jelentősebb hatások várhatóak, amelyek képesek lehetnek a jelenlegi gazdasági térstruktúrát módosítani, befolyásolni, mindezekkel hatást gyakorolni a gazdálkodási döntésekre.

A téma szempontjából fontos kiemelni a gazdasági szereplók felelósségét is a megfelelő fejlesztéspolitikai irányok kialakítása területén, a gazdaság számára szükséges prioritások hangsúlyozását és a fejlesztéspolitikai források eredményes hasznosulását, a kritikus tömeg kialakulását érdemes elősegíteni. Mindez hozzájárulhat Magyarország versenyképességének növeléséhez is.

\section{Lábjegyzet}

${ }^{1}$ Az adatokért köszönettel tartozom Béres Attilának, az NFÜ értékeléssel foglalkozó fóosztálya munkatársának, aki rendelkezésemre bocsátotta az adatbázist, amely az I. NFT keretében 2004 és 2006 között benyújtott összesen 40998 db pályázat adatait tartalmazza kistérségi bontásban. Az adatbázis az EMIR (Egységes Monitoring Információs Rendszer) adatain alapul, a lekérdezés idốpontja: 2008. március 26.

\section{Felhasznált irodalom}

Adler J. (1999): A magyar gazdaság fejlődésének néhány regionális sajátossága. Vezetéstudomány, 30. évf., 6. sz., 24-42. o.

Barca, F. (2009): An Agenda for a Reformed Cohesion Policy. A place-based approach to meeting European Union challenges and expecatations. Independent Report prepared at the request of Danuta Hübner, Comimissioner for Regional Policy 
Bélyácz I. - Kuti M. (2009): Külföldi múködőtőke és külsô eladósodás. Kísérlet a makrogazdasági tốkestruktúra új szempontú vizsgálatára. Közgazdasági Szemle, 56. évf., 2. sz., 133-154. o.

Benedek T. (2001): Külföldi tókebefektetések a regionális különbségek tükrében. Vezetéstudomány, 32. évf., 5. sz., 17-25. o.

Bouvet, F. (2003): European Union Regional Policy: Allocation Determinants and Effects on Regional Economic Growth. Job Market Paper www.econ. ucdavis.edu/graduate/fbouvet/job_market.pdf (2008.10.11.)

Csengódi S. - Csite A. - Felföldi Z. - Juhász M. (2006): Az I. Nemzeti Fejlesztési Terv forráselosztási mechanizmusai. Hét kistérség tapasztalatai. Európai Tükör, 11. évf., 9. sz., 74-100. o.

Csite A. - Felföldi Z. (2006): Az I. NFT forráselosztási mechanizmusai: 7 kistérség vizsgálata. Előadás az NFÜ értékelési konferenciáján, Budapest, november 8.

Csite A. - Németh N. (2008): Területi kiegyenlítés vagy a fejlettségi különbségek megerôsödése? Az I. Nemzeti Fejlesztési Terv települések közti forráselosztási mechanizmusainak többváltozós statisztikai vizsgálata. Vezetối összefoglaló. Pannon Kutató Bt., Budapest

DDRFÜ (2007): Pályázati források hasznosulásának vizsgálata. Dél-Dunántúli Regionális Fejlesztési Ügynökség Kht., Kaposvár

Dezsériné Major M. (2008): A kis- és középvállalatok pályázati aktivitása és hatásai vállalati felmérés alapján. Vállalkozás és Innováció, 2. évf., 2. sz., 88-105. o.

EC (2008): Zöld könyv a területi kohézióról. Előnyt kovácsolni a területi sokféleségból. A Biztosság közleménye a Tanácsnak, az Európai Parlamentnek, a Régiók Bizottságának és az Európai Gazdasági és Szociális Bizottságnak. Európai Bizottság, Brüsszel

EC (2010a): A Bizottság közleménye az Európai Parlamentnek, a Tanácsnak, az Európai Gazdasági és Szociális Bizottságnak, a Régiók Bizottságának és az Európai Beruházási Banknak. A gazdasági, szociális és területi kohézióról szóló ötödik jelentéssel kapcsolatos következtetések: a kohéziós politika jövője. Az Európai Közösségek Bizottsága, Brüsszel

EC (2010b): Európa 2020. Az intelligens, fenntartható és inkluzív növekedés stratégiája. A Bizottság közleménye. Európai Bizottság, Brüsszel

Ecostat (2008): A Nemzeti Fejlesztési Terv forrásainak felhasználása és néhány mérhető hatása. Időszaki közlemények, 28. sz., Ecostat Kormányzati Gazdaság- és Társadalom-stratégiai Kutató Intézet, Budapest

Enyedi Gy. (2010): Terület- és településfejlesztéssel kapcsolatos tudományos kutatások fő irányai és feladatai. Területi Statisztika, 50. évf., 4. sz., 398-405. o.

Erdốs T. (2006): Növekedési potenciál és gazdaságpolitika. Akadémiai Kiadó, Budapest

Farkas F. - Hadinger B. - Szücs P. (2007): A menedzsment alapjai. PTE KTK, Pécs
HBF (2006): Az I. Nemzeti Fejlesztési Terv forráselosztási mechanizmusai. Települések és kistérségek a fejlesztési versenyben. Kutatási összefoglaló. HBF Hungaricum Kft., Kecskemét

Horváth Gy. (1996): A magyar regionális politika és az európai kihívások. Vezetéstudomány, 27. évf., 1 sz., 17-29. o.

Horváth Gy. (2004): Regionális egyenlőtlenségek Európában. Magyar Tudomány, 165. évf., 9. sz., 962-977. o.

Horváth Gy. (2006): Differenciált kelet-közép-európai tér. Regionális teljesítôképesség és a területfejlesztés törvényi szabályozása. Falu Város Régió, 12. évf., 1. sz., 11-16. o.

Horváth Gy. (2010): A paradigmaváltás szükségessége a magyar területpolitikában. Gazdálkodás, 54. évf., 7. sz., 801-803. o.

Hrubi L. (2001): A területi gazdaságfejlesztés kihívásai. in: Petrétei J. (szerk.): Emlékkönyv Bihari Ottó egyetemi tanár születésének 80. évfordulójára. Pécs: PTE ÁJK MTA RKK DTI, 207-224. o.

Járosi P. - Koike, A. - Thissen, M. - Varga, A. (2009): Regionális fejlesztéspolitikai hatáselemzés térbeli számítható általános egyensúlyi modellel: A GMR-Magyarország SCGE modellje. Múhelytanulmány. Pécsi Tudományegyetem Közgazdaságtudományi Kar, Közgazdasági és Regionális Tudományok Intézete, Pécs

Kengyel Á. (2008): Kohézió és finanszírozás. Az Európai Unió regionális politikája és költségvetése. Akadémiai Kiadó, Budapest

Kornai J. (2007): Szocializmus, kapitalizmus, demokrácia és rendszerváltás. Akadémiai Kiadó, Budapest

KSH (2005) Területi Statisztikai Évkönyv 2004. Központi Statisztikai Hivatal, Budapest

KSH (2009) Területi Statisztikai Évkönyv 2008. Központi Statisztikai Hivatal, Budapest

Lehmann K. (2008): Az I. NFT hatásértékelése. Európai tapasztalatok. Előadás a Magyar Közgazdasági Társaság 46. Vándorgyúlésén. Eger, június 27.

Lóránd B. (2009): Konvergencia és fejlesztéspolitika az Európai Unióban és Magyarországon. A területi differenciáltságot befolyásoló hazai fejlesztéspolitika értékelése az I. Nemzeti Fejlesztési Terv pályázati forrásainak allokációja alapján. Doktori disszertáció. PTE KTK Regionális Gazdaságtan és Politika Doktori Iskola, Pécs

Lóránd B. (2010): Az Európai Unió kohéziós politikájának értékelése. Európai Tükör, 15. évf., 4. sz., 54-66. o.

Lukovics M. (2006): A magyar megyék és a fóváros versenyképességének empirikus vizsgálata. Területi Statisztika, 9.(46.) évf., 2. sz., 148-166. o.

MEH (2006): Európai Uniós támogatások közbenső értékelése. Az I. Nemzeti Fejlesztési Terv operatív programjainak, támogatásainak területi szempontú közbensô értékelése, korreláció vizsgálata. MEH-RFF TNMH - OTH - Pályázati Információs Központ, Budapest

MNB (2006): Elemzés a konvergencia-folyamatokról. Magyar Nemzeti Bank, Budapest

Molle, W. (2007): European Cohesion Policy. Routledge, London-New York 
Nagy Gy. (2010): A globális pénzügyi fiaskó néhány következménye az Európai Unióban. Fejlesztés és Finanszírozás, 8. évf., 1. sz., 41-50. o.

NFH (2004): Az NFT stratégiája és prioritásai. Nemzeti Fejlesztési Hivatal, Budapest. www.nfu.hu/download/700/ ii._strategia.pdf (2008.12.11.)

NFH (2006): Strukturális Alapok közbenső értékelése. Nemzeti Fejlesztési Hivatal, Budapest

NFÜ (2007): Európai Uniós támogatások kistérségi elemzése. Az I. Nemzeti Fejlesztési Terv operatív programjainak területi szempontú közbenső értékelése. NFÜ Kommunikációs Fóosztály, Budapest

NFÜ (2008): Vezetői tájékoztató. A 174 magyarországi kistérségnek az NFT pályázatain elért eredményeiról. NFÜ Informatikai és Tájékoztatási Fóosztály, Budapest

Pogátsa Z. (2007): Éltanuló válságban. Állam és piac a rendszerváltás utáni Magyarországon. Sanoma Kiadó, Bp.

Rechnitzer J. - Lados M. (2004): A területi stratégiáktól a monitoringig. Módszertan, gyakorlati praktikumok. Dialóg Campus Kiadó, Budapest-Pécs

Rodríguez-Pose, A. - Fratesi, U. (2002): Unbalanced development strategies and the lack of regional convergence in the EU. ERSA Congress Dortmund,
Szerb L. - Acs, J. Z. - Varga A. - Ulbert J. -Bodor É. (2004): Az új vállalkozások hatásai nemzetközi összehasonlításban. A Global Entrepreneurship Monitor kutatás, 2001-2003. - Közgazdasági Szemle, 51. évf., 7-8. sz., 679-698. o.

Szerb L. (1994): A regionális fejlesztéspolitika jövője Magyarországon. Vezetéstudomány, 25. évf., 8. sz., 4654. o.

Tétényi T. (2005): A strukturális beavatkozások társfinanszírozása az új tagállamokban. Szúk keresztmetszet vagy adagolás? Elő́itéletek és tények. in: Sorsfordító esztendő. A 42. Közgazdász-Vándorgyúlés előadásai. Budapest, TAS -11 Kft., 381-407. o.

Toroczkai A. - Hahn Cs. (2006): Európai uniós támogatási adatok területi értékelése. Területi Statisztika, 9.(46.) évf., 5. sz., 459-475. o.

Varga A. (2007): From the Geography of Innovation to Development Policy Analysis: the GMR-Approach. Múhelytanulmány. Pécsi Tudományegyetem Közgazdaságtudományi Kar, Közgazdasági és Regionális Tudományok Intézete, Pécs

Voszka É. (2006): Uniós támogatások - a redisztribúció új szakasza? Külgazdaság, 50. évf., 6. sz., 8-30. o.

\section{O N T E N T S}

\section{Studies ANd ARTICles}

\section{ULBERT, József}

In protection of dcf model .2

\section{BEDÓ, Zsolt}

The „contextual” corporate governance

\section{KOVÁCS, Kármen}

Relationships between advertising and market structure

\section{CSAPI, Vivien}

The role of real options in supply chain risk management

\section{LÁNYI, Beatrix}

Reasons and types of innovative co-operation in the chemical industry... . .38

\section{DUDÁS, Katalin}

Dimensions of the conscious consumer behaviour...47

\section{KISPÁL-VITAI, Zsuzsanna}

Relationship between co-operative identity

and social responsibility 56

\section{TITKOS, Csaba}

Ideal typical forms of knowledge transfer .64

\section{DEUTSCH, Nikolett}

Strategic opportunities of the vertically integrated enterprises in the European Union deregulated electricity markets

\section{LÓRÁND, Balázs}

The effects of the development and efficiency of Cohesion Policy on corporate decision making 